\title{
HYPOCALCAEMIC TETANY DEVELOPING WITHIN 36 HOURS OF BIRTH*
}

\author{
BY \\ W. S. CRAIG and M. F. G. BUCHANAN \\ From the Department of Paediatrics and Child Health, University of Leeds
}

(RECEIVED FOR PUBLICATION MAY 16, 1958)

\section{Introduction}

Paediatric literature contains many brief references to the occurrence of neonatal tetany. Clinical signs developed in the first week of life in only a small proportion of the recorded cases. The number of infants reported as showing signs of hypocalcaemic tetany within a few hours of birth is extremely small. Willi (1939) described eight and Bakwin (1937) four babies in whom tetany developed on the first day of life. In a more recent comprehensive study of the causes of tetany in infancy and childhood Gribetz (1957) uses the term 'first day tetany' when referring to the biochemical imvestigations of Gittleman and his co-workers. Gittleman, Pincus, Schmerzler and Saito (1956) made a special study of calcium levels on the first day of life and found low serum calcium levels with significant frequency in premature infants and in babies born at term to mothers with a history of abnormal pregnancy and/or labour.

In October, 1956, the occurrence of violent neuromuscular hyperexcitability in the day-old baby of a diabetic mother in the Leeds Maternity Hospital aroused suspicions of tetany. The baby's serum calcium was $6.2 \mathrm{mg}$. per $100 \mathrm{ml}$. Within a period of one month similar findings were encountered in the newly born babies of two other mothers with diabetes mellitus. A detailed clinical study of babies newly born to diabetic mothers was commenced. As the study proceeded a resemblance was noted between the movement pattern in these babies and that seen in a number of newly born premature infants of healthy mothers. The resemblance was one of quality rather than severity. Low serum calcium levels were obtained in a high proportion of the premature babies with neuromuscular hyperactivity. A decision was therefore made to extend the investigation to include all babies manifesting neuromuscular hyperexcitability shortly after birth.

* Based upon a paper given at the Annual Meeting of the British Paediatric Association, 1958, and illustrated by a cinematograph flm.
The primary purpose of this article is to present the findings in connexion with 26 babies in whom hypocalcaemic tetany developed within 40 minutes to 36 hours of birth. As a corollary to the main study findings are also given in infants who in the first 36 hours of life either $(a)$ showed clinical signs suggestive of tetany in the absence of a low serum calcium level (seven infants), or $(b)$ presented no abnormal clinical features despite the presence of a low serum calcium level (two infants).

\section{Clinical Material}

Of the 35 babies included in the total study, 30 were born in the Leeds Maternity Hospital, three in St. Mary's Hospital, Leeds, and two at home prior to admission to Leeds Maternity Hospital. For the purposes of the study tetany was considered to be present if exaggerated neuromuscular hyperactivity was associated with a total serum calcium level of $8 \mathrm{mg}$. per $100 \mathrm{ml}$. or less. Total serum calcium determinations were obtained by the permanganate titration method. Ultrafilterable calcium levels were estimated in a limited number of cases. The method employed was the one described by Lavietes (1937) and used by Hopkins, Howard and Eisenberg (1952). The decision to regard a total serum calcium of $8 \mathrm{mg}$. (and less) per $100 \mathrm{ml}$. as low takes account of the recorded opinions of other workers. Bakwin (1937), Willi (1939) and Kendig (1942) consider that a serum calcium level below $8 \mathrm{mg}$. per $100 \mathrm{ml}$. provides confirmatory evidence of a clinical diagnosis of tetany. In their comprehensive laboratory study Gittleman et al. (1956) regarded total serum calcium levels under $8 \mathrm{mg}$. per $100 \mathrm{ml}$. as low. Studying a series of 55 healthy newborn babies Mitchell and Stevenson (1932) found a serum calcium level of under $8 \mathrm{mg}$. per $100 \mathrm{ml}$. in only one infant. In another control series of 48 healthy newborn babies investigated by Dodd and Rapoport (1949) the serum calcium level was above $8 \mathrm{mg}$. per $100 \mathrm{ml}$. in every instance. 


\section{Clinical Observations}

\section{Hypocalcaemic Tetany (26)}

(1) The Clinical Picture. Neuromuscular hyperactivity associated with hypocalcaemia was noted in 26 infants. All infants were under observation while being nursed in incubators. Details concerning these babies are given in Table 1 . In each case signs were first noted within 36 hours of birth. The severity of the clinical picture varied, being violent in seven, pronounced in 14 and mild in five babies.

TABLE 1

HYPOCALCAEMIC TETANY WITHIN 36 HOURS OF BIRTH

\begin{tabular}{|c|c|c|c|c|}
\hline \multicolumn{3}{|c|}{ Neuromuscular Excitability } & \multicolumn{2}{|c|}{$\begin{array}{c}\text { Total Serum Calcium* } \\
(\mathrm{mg} . / 100 \mathrm{ml} .)\end{array}$} \\
\hline Degree & $\begin{array}{l}\text { Age at } \\
\text { Onset } \\
\text { (hr.) }\end{array}$ & $\begin{array}{l}\text { Duration } \\
(\mathrm{hr} .)\end{array}$ & $\begin{array}{l}\text { On 2nd day } \\
\text { of life }\end{array}$ & $\begin{array}{l}\text { Lowest estimate in } \\
1 \mathrm{st} 72 \mathrm{hr} \text {. of life }\end{array}$ \\
\hline $\begin{array}{l}\text { Violent } \\
\text { (7) }\end{array}$ & $\begin{array}{r}22 \\
10 \\
1 \\
24 \\
10 \\
8 \\
1\end{array}$ & $\begin{array}{r}108 \\
120 \\
130 \\
32 \\
62 \\
30 \\
21\end{array}$ & $\begin{array}{l}2 \cdot 6 \\
5 \cdot 1 \dagger \\
6 \cdot 0 \\
6 \cdot 2 \\
7 \cdot 1 \\
7 \cdot 3 \\
8 \cdot 0\end{array}$ & $\begin{array}{l}2 \cdot 6 \\
5 \cdot 1 \\
6 \cdot 0 \\
6 \cdot 2 \\
6 \cdot 8 \\
6 \cdot 8 \\
8 \cdot 0\end{array}$ \\
\hline$\underset{\substack{\text { Pro- } \\
\text { nounced }}}{(14)}$ & $\begin{array}{r}19 \\
4 \\
7 \\
36 \\
17 \\
24 \\
6 \\
22 \\
22 \\
14 \\
18 \\
13 \\
6 \frac{1}{2} \\
24\end{array}$ & $\begin{array}{r}36 \\
77 \\
72 \\
24 \\
52 \\
36 \\
18 \\
48 \\
60 \\
72 \\
32 \\
90 \\
130 \\
48\end{array}$ & $\begin{array}{l}6 \cdot 1 \\
6 \cdot 4 \\
6 \cdot 7 \\
6 \cdot 8 \\
6 \cdot 8 \\
7 \cdot 2 \\
7 \cdot 3 \\
7 \cdot 3 \\
7 \cdot 4 \\
7 \cdot 6 \\
7 \cdot 8 \\
7 \cdot 9 \dagger \\
8 \cdot 0 \\
8 \cdot 0\end{array}$ & $\begin{array}{l}5 \cdot 7 \\
6 \cdot 4 \\
4 \cdot 6 \\
6 \cdot 8 \\
6 \cdot 8 \\
6 \cdot 8 \\
7 \cdot 3 \\
6 \cdot 5 \\
7 \cdot 4 \\
7 \cdot 6 \\
7 \cdot 8 \\
7 \cdot 9 \\
8 \cdot 0 \\
8 \cdot 0\end{array}$ \\
\hline$\underset{(5)}{\text { Mild }}$ & $\begin{array}{r}33 \\
17 \\
24 \\
4 \\
22\end{array}$ & $\begin{array}{l}24 \\
24 \\
36 \\
40 \\
24\end{array}$ & $\begin{array}{l}5 \cdot 6 \\
7 \cdot 0 \\
7 \cdot 1 \\
7 \cdot 8 \\
7 \cdot 9\end{array}$ & $\begin{array}{l}5 \cdot 6 \\
7 \cdot 0 \\
7 \cdot 1 \\
7 \cdot 3 \\
7 \cdot 3\end{array}$ \\
\hline
\end{tabular}

* The concentration of calcium in the cord blood was estimated in 21 cases. The lowest level obtained was $9.9 \mathrm{mg}$., the average being $10.5 \mathrm{mg}$. per $100 \mathrm{ml}$.

$\dagger$ Given exchange transfusion on account of haemolytic disease.

A detailed description of the signs in certain of the infants included in this series has already been recorded (Craig, 1958). Clinical signs were characterized by an abnormal movement pattern consisting of alternating phases of generalized hyperactivity and silent, exhausted immobility. Hyperactivity took the form of coarse waving movements of the limbs, agitated vibrations of the hands and fine persistent tremors of the fingers. The toes were splayed out. In severe cases the cry was squeaky and hollow and the expression one of distress. In all babies there were periods of apnoea and during phases of severe agitation the entire body acquired a grey cyanotic tinge. Cyanotic apnoea not due to aspiration of fluid was particularly liable to occur at the time of feeds.

Other features noticed in a proportion of cases were tachypnoea, tachycardia, repetitive blinking of partially closed eyelids, and the ejection of minute meconium stools. Trousseau's and Chvostek's signs were not present but in four babies a position simulating pedal spasm was assumed following local pressure on the lower limbs. Laryngeal stridor was a feature in two babies. Phases of neuromuscular hyperexcitability occurred spontaneously, and as a result of stimulus by touch, noise, vibration and light. Repeated stimuli resulted in temporary diminution of response. Spontaneous phases recurred at short intervals over varying periods of 12 hours to six days. There were convulsions in four infants. Details of the abnormal movement pattern in these 26 babies are summarized in Table 2.

TABLE 2

CLINICAL FEATURES OF HYPOCALCAEMIC TETANY WITHIN 36 HOURS OF BIRTH 26 INFANTS

Generalized neuromuscular hyperexcitability $\quad \ldots \quad$. 26

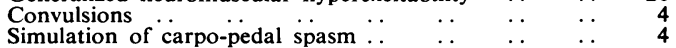

Spontaneous attacks of apnoea and/or cyanosis

Apnoea stimulated by feeding

Frequent regurgitation

Hollow or squeaky cry

Stridor

Tachycardia

Tachypnoea

Complete disappearance of abnormal clinical features

Total serum calcium level of $10 \mathrm{mg}$. or more per $100 \mathrm{ml}$. on or before seventh day of life

None of the babies was given cow's milk or alkaline therapy prior to the onset of tetany and at no time did any suffer from vomiting, diarrhoea or excessive fluid loss.

(2) The Biochemical Picture. Biochemical findings in the 26 examples of hypocalcaemic tetany are given in Table 3.

(3) The Influence of Calcium Therapy. Calcium was given to five babies with clinically violent tetany. The results were not uniformly conclusive. Rapid improvement followed oral administration in one infant, and intramuscular administration in another. In the remaining three babies the impression was gained that combined intramuscular and oral therapy may have accelerated the disappearance of clinical signs of tetany.

(4) The Obstetric Background. Details are summarized in Table 4. There were two cases of placenta praevia, one being associated with toxaemia. Delivery was spontaneous in 15 cases and by caesarean section in 11 cases. 
TABLE 3

BIOCHEMICAL FINDINGS DURING FIRST 4 DAYS OF LIFE IN HYPOCALCAEMIC TETANY: 26 INFANTS

\begin{tabular}{|c|c|c|c|c|c|c|}
\hline Baby & Day & $\begin{array}{l}\text { Total Ser. Ca. } \\
\text { (mg. } / 100 \text { ml.) }\end{array}$ & $\begin{array}{l}\text { Ultrafilt. Ca. } \\
\text { (mg./100 ml.) }\end{array}$ & $\begin{array}{l}\text { Phosphorus } \\
\text { (mg. } / 100 \text { ml.) }\end{array}$ & $\begin{array}{l}\text { Alk. Phosph. } \\
\text { (Units*/100 ml.) }\end{array}$ & $\begin{array}{c}\text { Blood Urea } \\
\text { (mg./100 ml.) }\end{array}$ \\
\hline \multicolumn{7}{|c|}{ (A) Violent Hyperexcitability (7) } \\
\hline Ma & 2 & $\begin{array}{r}6 \cdot 2 \\
10 \cdot 0\end{array}$ & 二 & $\overline{3 \cdot 0}$ & $\overline{23}$ & $\overline{68}$ \\
\hline$T$ & $\begin{array}{l}2 \\
4\end{array}$ & $\begin{array}{l}2 \cdot 6 \\
8 \cdot 1\end{array}$ & $=$ & $\begin{array}{l}5 \cdot 7 \\
8 \cdot 4\end{array}$ & 36 & $\begin{array}{r}176 \\
92\end{array}$ \\
\hline G & $\frac{1 \frac{1}{2}}{2}$ & $\begin{array}{l}8 \cdot 0 \\
6 \cdot 0\end{array}$ & $\overline{-}$ & $\overline{5 \cdot 6}$ & $\overline{-}$ & 二 \\
\hline H & $\begin{array}{l}2 \\
3 \\
4\end{array}$ & $\begin{array}{l}6.8 \\
7.1 \\
8.6\end{array}$ & $\overline{3 \cdot 1}$ & $\overline{7 \cdot 0}$ & $\frac{21}{二}$ & $\frac{48}{42}$ \\
\hline Mo & 2 & $\begin{array}{l}6 \cdot 8 \\
7 \cdot 3\end{array}$ & $\overline{3 \cdot 5}$ & $5 \cdot 0$ & $\begin{array}{l}24 \\
28\end{array}$ & $\begin{array}{l}30 \\
22\end{array}$ \\
\hline $\mathbf{R}$ & $3^{\frac{1}{2}}$ & $5 \cdot 1$ & $=$ & $\overline{5 \cdot 3}$ & $=$ & $\overline{83}$ \\
\hline G & 1 & $8 \cdot 0$ & - & $5 \cdot 6$ & - & - \\
\hline
\end{tabular}

(B) Pronounced Hyperexcitability (14)

\begin{tabular}{|c|c|c|c|c|c|c|}
\hline $\mathbf{S}$ & $\begin{array}{l}2 \\
3\end{array}$ & $\begin{array}{l}4.6 \\
6.7\end{array}$ & $\overline{3 \cdot 6}$ & $6 \cdot 8$ & 18 & $\underline{44}$ \\
\hline $\mathbf{L}$ & $\frac{1}{2}$ & $\begin{array}{l}7 \cdot 3 \\
7 \cdot 8\end{array}$ & $\begin{array}{l}3.6 \\
2 \cdot 9\end{array}$ & 二 & $=$ & 46 \\
\hline $\mathbf{w}$ & $\begin{array}{l}\frac{\frac{1}{2}}{1 \frac{1}{2}} \\
2 \frac{1}{4}\end{array}$ & $\begin{array}{l}8 \cdot 3 \\
6 \cdot 8 \\
7 \cdot 2\end{array}$ & $\overline{\overline{4.9}}$ & $\begin{array}{l}4 \cdot 5 \\
=\end{array}$ & $=$ & ב6 \\
\hline D & $\frac{1+}{2}$ & $\begin{array}{l}6.4 \\
8.0\end{array}$ & $\overline{4 \cdot 9}$ & $5 \cdot 0$ & $=$ & 32 \\
\hline $\mathbf{N}$ & $\frac{1 \frac{1}{2}}{2 \frac{1}{2}}$ & $\begin{array}{l}6.5 \\
7.4\end{array}$ & $\overline{4.5}$ & $\overline{3 \cdot 0}$ & $\overline{20}$ & $\overline{35}$ \\
\hline $\mathbf{N}$ & $\begin{array}{l}1 \frac{1}{2} \\
2 \frac{1}{2}\end{array}$ & $\stackrel{7 \cdot 3}{-}$ & $\stackrel{4 \cdot 1}{-}$ & 二 & 二 & $\overline{31}$ \\
\hline$T$ & $1 \frac{8}{4}$ & $6 \cdot 1$ & $3 \cdot 2$ & - & - & 35 \\
\hline $\mathbf{T}$ & 2 & $8 \cdot 0$ & - & $7 \cdot 1$ & 26 & 62 \\
\hline $\mathbf{W}$ & $\frac{1 \frac{1}{2}}{\frac{1}{2}}$ & $\begin{array}{l}6.8 \\
7.2 \\
\end{array}$ & $\overline{4.9}$ & $4 \cdot 5$ & $=$ & 46 \\
\hline $\mathbf{F}$ & 2 & $7 \cdot 6$ & - & - & - & - \\
\hline $\mathbf{S}$ & $\begin{array}{l}1 \\
2 \\
\end{array}$ & $\begin{array}{l}5.7 \\
6.1 \\
\end{array}$ & $\overline{3 \cdot 2}$ & $=$ & 二 & 35 \\
\hline $\mathrm{Wm}$ & $\frac{1}{2} \frac{1}{2}$ & $\stackrel{6 \cdot 8}{-}$ & $=$ & $=$ & 二 & 二 \\
\hline $\mathbf{w}$ & $1 \frac{\frac{3}{3}}{4}$ & $\begin{array}{l}8.1 \\
7.9\end{array}$ & 二 & $\begin{array}{r}5.4 \\
5.0\end{array}$ & 二 & 二 \\
\hline McG & $\begin{array}{l}11 \\
2 \\
31\end{array}$ & $\begin{array}{l}9 \cdot 0 \\
8.0 \\
9 \cdot 8\end{array}$ & $=$ & $=$ & $\bar{z}$ & 二 \\
\hline \multicolumn{7}{|c|}{ (C) Mild Hyperexcitability (5) } \\
\hline I & $1 t$ & $7 \cdot 0$ & $3 \cdot 5$ & - & - & - \\
\hline $\mathbf{s}$ & $\frac{1}{2}$ & $\begin{array}{l}7 \cdot 8 \\
7 \cdot 3\end{array}$ & 二 & $5 \cdot 8$ & 9 & 53 \\
\hline $\mathbf{M}$ & $\begin{array}{l}2 \\
3\end{array}$ & $\begin{array}{l}5.6 \\
7.0 \\
\end{array}$ & $2 \cdot 8$ & $\overline{7 \cdot 4}$ & 二 & $\overline{34}$ \\
\hline $\mathbf{s}$ & 11 & $7 \cdot 9$ & - & - & - & - \\
\hline Mac & $2^{\frac{1}{2}}$ & $\begin{array}{l}7 \cdot 1 \\
7 \cdot 5\end{array}$ & $\overline{3.9}$ & $=$ & 20 & 35 \\
\hline
\end{tabular}

* King Armstrong units. 
TABLE 4

OBSTETRIC BACKGROUND IN HYPOCALCAEMIC TETANY WITHIN 36 HOURS OF BIRTH: 26 INFANTS

A. Born at Term (38 weeks and over)

Healthy mother: spontaneous delivery: breech .. 1 caesarean section: prolonged

labour.. .. .. .. caesarean section: placenta $\cdots$ praevia
elective caesarean section: ective caesarean section:
disproportion

B. Short Gestation Period (less than 38 weeks) Healthy mother: spontaneous delivery: vertex ..4 both infants of a twin pregnancy $\ldots 2$ one infant of twin pregnancies $\ldots 2$ Diabetic mother: $\begin{array}{lll}\text { one infant of twin pregnancies } & \ldots & 2 \\ \text { spontaneous delivery: vertex } & \ldots & 3\end{array}$ elective caesarean section Pre-diabetic mother: spontaneous delivery: vertex.. 1 Eclampsia and placenta praevia: caesarean section ...

\section{Neuromuscular Activity in the Absence of Hypocalcaemia}

A tentative diagnosis of tetany based on clinical observations was made on the second day of life in seven infants in whom the total serum calcium level was above $8 \mathrm{mg}$. per $100 \mathrm{ml}$. The clinical picture was pronounced in six and mild in one. All seven babies were delivered spontaneously, presentation being by the vertex in five cases and by the breech in two. The estimated gestation period was 37 weeks or less in the case of five babies: and 40 and 41 weeks in the remaining two. In no case was there a history of maternal toxaemia. Two of the premature infants were the firstborn of twin pregnancies (see IV (2) below). The onset of neuromuscular hyperexcitability took place three, 16, 20, 23 and 29 hours after birth and persisted for $12,30,72,24$ and 72 hours respectively in five babies. The corresponding percentages of serum calcium on the second day of life were 8.5 , $9 \cdot 3,8 \cdot 8,11 \cdot 6$ and $8 \cdot 7 \mathrm{mg}$.

In two instances neuromuscular hyperexcitability in the absence of hypocalcaemia occurred in babies given exchange transfusions.

\section{Hypocalcaemia without Associated Neuromuscular Hyperexcitability}

Two examples were encountered of hypocalcaemia not associated with neuromuscular hyperexcitability. Both occurred in infants newly born to diabetic mothers. In each case the estimated gestation period was 36 weeks, delivery was spontaneous, and the serum calcium level on the second day of life was $7 \cdot 3 \mathrm{mg}$. per $100 \mathrm{ml}$.

\section{Some Special Groups}

The 35 infants reported in this study include a high proportion of infants born prematurely, a number of babies born to diabetic mothers, several infants of twin pregnancies and four babies given replacement transfusions on account of haemolytic disease.

(1) Premature Infants. The estimated gestation period of 29 babies was less than 38 weeks, ranged from 31 to 37 weeks and averaged 36 weeks. Ten of the infants were born to diabetic mothers, the average birth weight being $7 \mathrm{lb} .7 \mathrm{oz}$. The birth weight of one baby born to a pre-diabetic mother was $6 \mathrm{lb} .12 \mathrm{oz}$. The average birth weight of the remaining 18 premature infants was $4 \mathrm{lb}$. Of the 29 premature babies hypocalcaemia was a feature of 24 , being associated with violent, pronounced and mild hyperexcitability in five, 13 and four cases respectively. In two babies there was no hyperexcitability despite the presence of hypocalcaemia; and hyperexcitability was present in five infants in whom the serum calcium was above $8 \mathrm{mg}$. per $100 \mathrm{ml}$.

(2) Twin Pregnancies. Hypocalcaemic tetany was found in the babies of four twin pregnancies. In one such pregnancy both babies were involved; and in another both infants showed clinical signs of pronounced neuromuscular hyperexcitability but only one infant had a total serum calcium level under $8 \mathrm{mg}$. per $100 \mathrm{ml}$. In each of two other pregnancies one infant showed evidence of hyperexcitability and was the only infant with hypocalcaemia. A feature of each of the four twin pregnancies was that the total serum calcium level was lower in the second than the first live-born infant. Details are given in Table 5.

TABLE 5

SERUM CALCIUM LEVELS IN FOUR TWIN PREGNANCIES

\begin{tabular}{|c|c|c|c|c|c|}
\hline Baby & $\begin{array}{c}\text { Hyper- } \\
\text { excitability }\end{array}$ & $\begin{array}{l}\text { Total Serum } \\
\text { Calcium } \\
\text { (mg. } / 100 \mathrm{ml} .)\end{array}$ & $\begin{array}{c}\text { Birth } \\
\text { (lb. }\end{array}$ & $\begin{array}{c}\text { Weight } \\
\text { oz.) }\end{array}$ & $\begin{array}{l}\text { Maturity } \\
\text { (weeks) }\end{array}$ \\
\hline $\begin{array}{l}\mathbf{N} 1 \\
\mathbf{N}\end{array}$ & $\begin{array}{l}\text { Pronounced } \\
\text { Pronounced }\end{array}$ & $\begin{array}{l}7 \cdot 4 \\
7 \cdot 3\end{array}$ & $\begin{array}{l}4 \\
5\end{array}$ & $\begin{array}{l}6 \\
7\end{array}$ & $\begin{array}{l}35 \\
35\end{array}$ \\
\hline $\left.\begin{array}{ll}\mathrm{T} & 1 \\
\mathrm{~T} & 2\end{array}\right\}$ & $\begin{array}{l}\text { Nil } \\
\text { Pronounced }\end{array}$ & $\begin{array}{l}8 \cdot 6 \\
5 \cdot 7\end{array}$ & $\begin{array}{l}5 \\
3\end{array}$ & $\begin{array}{r}4 \\
14\end{array}$ & $\begin{array}{l}36 \\
36\end{array}$ \\
\hline $\left.\begin{array}{ll}\mathbf{S} & 1 \\
\mathbf{S} & 2\end{array}\right\}$ & $\begin{array}{l}\text { Pronounced } \\
\text { Pronounced }\end{array}$ & $\begin{array}{l}8 \cdot 8 \\
7 \cdot 8\end{array}$ & $\begin{array}{l}3 \\
3\end{array}$ & $\begin{array}{l}9 \\
6\end{array}$ & $\begin{array}{l}34 \\
34\end{array}$ \\
\hline $\left.\begin{array}{ll}\text { Mc } & 1 \\
\text { Mc } & 2\end{array}\right\}$ & $\begin{array}{l}\text { Nil } \\
\text { Mild }\end{array}$ & $\begin{array}{l}8 \cdot 3 \\
7 \cdot 1\end{array}$ & $\begin{array}{l}3 \\
3\end{array}$ & $\begin{array}{l}10 \\
13\end{array}$ & $\begin{array}{l}33 \\
33\end{array}$ \\
\hline
\end{tabular}

One of the infants with pronounced neuromuscular agitation in the absence of hypocalcaemia was a twin, the other product of the pregnancy being a macerated foetus.

None of these babies was born to a diabetic mother. 
(3) Infants Born to Diabetic Mothers. Ten babies with clinical tetany were born to mothers with diabetes mellitus and one to an obese mother with a pre-diabetic type of glucose tolerance curve. All 11 infants were premature and all were singletons. Of the 11 babies, 10 gave total serum calcium levels below $8.0 \mathrm{mg}$. per $100 \mathrm{ml}$, the values ranging from 2.6 to $7.5 \mathrm{mg}$. $\%$. In the remaining baby the corresponding figure was $8.0 \mathrm{mg}$. per $100 \mathrm{ml}$. Two infants (see section III) with low serum calcium levels showed no clinical evidence of abnormal neuromuscular instability. They were unique in this respect among all babies included in this investigation. In babies born to diabetic mothers neuromuscular hyperexcitability was violent in four, pronounced in four and mild in two infants. Clinical signs of tetany in the baby of the prediabetic mother were violent.

During the period of this investigation only three babies who had been newly born to diabetic mothers were found to show neither neuromuscular hyperexcitability nor hypocalcaemia.

(4) Exchange Transfusions. Pronounced or violent neuromuscular hyperexcitability was encountered in four babies given exchange transfusions on account of haemolytic disease. A total serum calcium level below $8 \mathrm{mg}$. per $100 \mathrm{ml}$. was obtained in two cases. In the interval between the commencement and completion of transfusion a fall of $3 \mathrm{mg}$. per $100 \mathrm{ml}$. was recorded in one baby, and a fall of $2 \mathrm{mg}$. per $100 \mathrm{ml}$. in another. Potassium levels were not estimated. Blood used for the exchange transfusions was citrated and had been stored for a period not exceeding five days. No calcium preparations were given during the transfusions.

\section{Discussion}

Biochemical Considerations. It is known that the serum calcium level falls transitorily during the first few days of life (Editorial, 1950). Gittleman et al. (1956) noted that in a number of newborn infants the concentration of calcium in the serum was less than $8 \mathrm{mg}$. per $100 \mathrm{ml}$. on the first day of life. They found that the incidence of hypocalcaemia was greater in infants delivered by caesarean section and in premature infants than in babies delivered spontaneously at term. Respiratory embarrassment, a tendency to regurgitate, convulsions, tremors and twitching of the extremities were seen in a number of the premature babies, and infants delivered by caesarean section (Gittleman, 1957). Zetterström and Arnhold (1958) stress the frequent occurrence of hypocalcaemia in the newly born babies of diabetic mothers. The occurrence of 'first-day hypocalcaemia' is referred to by Gribetz (1957) and has been demonstrated by Bruck and Weintraub (1955).

Clinical Approach. The investigations carried out by Gittleman et al. (1956) and Bruck (1955) were concerned primarily with biochemical findings. By way of contrast the present study is based primarily upon clinical observations. Admittedly the study is of only limited scale. It can be said, however, that despite its contrasting approach the results are in many respects in keeping with those of the two American investigations. The present series provides confirmatory evidence of a noteworthy incidence of hypocalcaemia in the early hours of life more especially among premature infants, babies born to diabetic mothers, and infants delivered by caesarean section. It is of interest too that while five of the 20 premature infants with hypocalcaemia in the present series were the products of twin pregnancies the premature infants in Gittleman's series included a number of twins. Our findings further resemble those of Gittleman (1957) in that the serum calcium levels in twins of the same pregnancy were usually different.

A more important result of the present study is evidence of the presence on the first or second day of life of a characteristic clinical picture of neuromuscular excitability in a large proportion of infants in whom there is 'first-day hypocalcaemia'. The association of neuromuscular hyperexcitability with hypocalcaemia warrants use of the term tetany, and is in accordance with views expressed by Bakwin (1937, 1939), Shannon (1934), Willi (1939), Bass (1942) and Kendig (1942).

Correlation of Clinical and Biochemical Findings. In their investigation of clinical tetany appearing between the first and thirteenth day of life Dodd and Rapoport (1949) found an approximate parallelism between the severity of symptoms and the depression of calcium levels. They record that the serum calcium varied between 6 and $9 \mathrm{mg}$. per $100 \mathrm{ml}$. in the infants with clinical tetany, although in a few babies with 'mild to moderate signs' levels of above $9 \mathrm{mg}$. were obtained.

The findings in our series of infants in whom clinical signs of tetany developed within 36 hours of birth do not reveal any rigid parallelism between the severity of clinical signs and the depression of calcium concentrations. It is probably significant, however, that in clinically violent cases the total serum calcium level averaged $6 \mathrm{mg}$. per $100 \mathrm{ml}$. while the corresponding figure for all other cases with manifest signs was $7 \mathrm{mg}$. per $100 \mathrm{ml}$. This may be 
an over-simplification. To some extent the physical tone and strength of an infant determine the severity of general systemic reactions to underlying trauma, infection or biochemical disturbance. This is evident in the subdued nature of the convulsions which are seen in small premature infants with severe intracranial trauma, meningitis or pyelonephritis. In the present series of infants an approximate relationship existed between birth weight and the clinical picture: the average birth weight of infants with violent, pronounced and moderate clinical tetany was $6 \mathrm{lb} .12 \mathrm{oz} ., 5 \mathrm{lb} .15 \mathrm{oz}$. and $4 \mathrm{lb} .10 \mathrm{oz}$. respectively. This in turn may be related to the positive correlation between birth weight of the premature infant and the concentration of calcium in the plasma noted by Gittleman and Pincus (1951).

A further point of interest is that Dodd regarded a total serum calcium level of less than $9 \mathrm{mg}$. \% as evidence of hypocalcaemia in the newborn. Had this standard been applied in the present series six of the seven infants we have regarded as examples of neuromuscular hyperactivity in the absence of hypocalcaemia (section II) would have been included among babies with hypocalcaemic tetany (section I). Another consideration is the interval of time between the onset of clinical signs of tetany and the taking of specimens for calcium estimations. As already emphasized clinical signs appeared within 36 hours of birth in every baby. An endeavour was made to obtain serum on the second day of life as a routine. The need to minimize disturbance of the babies ruled out any question of subsequent daily estimates. Almost certainly therefore the lowest concentration of calcium in the serum was not determined in every case. This is of importance because we gained the impression that although an approximate parallelism existed in the individual case between the trend of the clinical pattern and that of the serum calcium level, clinical signs of tetany tended to precede the appearance of pronounced hypocalcaemia, and the gradual disappearance of clinical signs tended to lag behind elevation of the serum calcium to a normal level.

The absolute level to which the serum calcium falls may not be the only factor of significance. Severe clinical tetany developed during exchange. blood transfusions in two cases in which the serum level did not fall below $8 \mathrm{mg}$. per $100 \mathrm{ml}$. The fall in level in each of these cases, however, was considerable and occurred within one and a half hours (section IV (4)). It is possible, therefore, that separately or jointly the speed and magnitude of the depression of calcium concentration may be of importance. Farquhar and Smith (1958) have investigated the disturbance of electrolyte balance which occurs during exchange transfusion. They found that the serum potassium level frequently increases and the calcium ion falls irrespective of the total serum calcium, creating conditions favouring the development of neuromuscular hyperexcitability. Estimates of serum potassium levels were not made in our study. In this study four infants given exchange transfusions, including the two referred to above, developed neuromuscular hyperexcitability in association with hypocalcaemia, and it is of interest that in three of the infants the first evidence of irritability was present before transfusion was commenced.

Differentiation of Abnormal from Normal. There is no arbitrary level of serum calcium which serves to distinguish an abnormally low from a normal concentration of calcium in the serum of the newborn infant. This applies especially to infants aged only 1 or 2 days in view of the temporary physiological fall in serum calcium level which occurs at this time. Midwives with prolonged experience of the care of premature infants are agreed that 'jumpiness', or 'preminess' as some term it, is a feature in the first few days of life of many of the smallest infants for whom they are responsible. In the present study neuromuscular hyperexcitability was noted in 27 premature babies (section IV (1)). It is probable that these examples of clinical tetany represent an intensified form of the clinical 'ditheriness' characteristic of a significant proportion of small premature babies in general. If this postulate is correct it can be argued with justification that just as no clear line of demarcation exists between physiological and pathological hypocalcaemia, so there is no definable clinical feature differentiating normal from abnormal neuromuscular excitability. This does not invalidate application of the term tetany to cases in which neuromuscular excitability and hypocalcaemia are found in association. It does, however, suggest that hypocalcaemic tetany per se occurring within 36 hours (say) of birth should be regarded as an exaggeration of a normal physiological state rather than as a distinct abnormal clinico-biochemical entity. The fact that unusual clinical and biochemical features disappear spontaneously gives support to this view.

It has been said that 'the concurrence of clinical tetany and hypocalcaemia [in the newborn] may suggest a causal relationship but this has not been clearly established' (Editorial, 1950). Observations made in this study do not clarify the continuing uncertainty in this connexion. They do, however, afford evidence that the occurrence of clinical tetany 
within 36 hours of life is probably favoured by a number of those factors which Gittleman et al. (1956) found contributed to hypocalcaemia on the first day of life. These factors include premature birth, delivery by caesarean section and maternal diabetes. It is possible that multiple pregnancy may be another factor.

\section{Summary}

Hypocalcaemic tetany is defined as abnormal neuromuscular hyperexcitability associated with a total serum calcium level of $8 \mathrm{mg}$. per $100 \mathrm{ml}$. or less.

The occurrence of hypocalcaemic tetany within 40 minutes to 36 hours of birth in 26 babies is described.

'Recovery' was complete in all cases.

Details of the clinical and biochemical findings are given.

The significance of the data presented is discussed.

Generous assistance was received from many colleagues including the consultant obstetrical, resident medical and midwifery staffs of the Leeds Maternity Hospital and St. Mary's Hospital, Leeds. Particularly valuable help was given by Miss M. Pattullo, S.R.N., S.C.M., and
Dr. M. Sturges. Routine laboratory examinations were undertaken by Mr. R. K. Martindale of the Leeds Maternity Hospital. Confirmatory estimates were kindly carried out under the direction of Dr. W. Goldie at St. James's Hospital, Leeds, or of Dr. W. W. Payne and Dr. R. H. Wilkinson at The Hospital for Sick Children, London. Estimates of ultrafilterable serum calcium were made at the last-named hospital. Valuable assistance in obtaining references was given by the Librarian, The Royal College of Physicians, Edinburgh.

\section{REFERENCES}

Bakwin, H. (1937). Amer. J. Dis. Child., 54, 1211.

Bas (1939). J. Pediat., 14, 1.

Bass, M. H. (1942). J. Mt Sinai Hosp., 9, 314

Bruck, E. and Weintraub, D. H. (1955). A.M.A. Amer. J. Dis. Child., 90, 653.

Craig, W. S. (1958). Pediatrics, 22, 297.

Dodd, K. and Rapoport, S. (1949). Amer. J. Dis. Child., 78, 537.

Editorial (1950). Quart. Rev. Pediat., 5, 271.

Farquhar, J. W. and Smith, H. (1958). Arch. Dis. Childh., 33, 142.

Garquhar, J. W. and Smith, H. (1958). Arch. Dis.

and Pincus, J. B. (1951). Pediatrics, 8, 778.

,--1 , Schmerzler, E. and Saito, M. (1956). Ibid., 18, 721

Gribetz, D. (1957). A.M.A.J. Dis. Child., 94, 301

Hopkins, T., Howard, J. E. and Eisenberg, H. (1952). Bull. Johns Hopk. Hosp. 91, 1 .

Kendig, E. L., (1942). J. Pediat., 21, 510

Lavietes, P. H. (1937). J. biol. Chem., 120, 267.

Mitchell, A. G. and Stevenson, F. E. (1932). J. Amer. med. Ass., 99, 1502 .

Shannon, W. R. (1934). Arch. Pediat., 51, 23.

Willi, H. (1939). Mschr. Kinderheilk 80, 2309.

Zetterstrom, R. and Arnhold, R. G. (1958). Acta paediat. (Uppsala), 47, 107. 